\title{
Effects of dietary cottonseed meal protein levels on growth and feed utilization of Nile tilapia, Oreochromis niloticus $\mathbf{L}$
}

\author{
${ }^{1 *}$ AGBO, N W ; ${ }^{2}$ MADALLA, $\mathbf{N} ;{ }^{3}$ JAUNCEY, K \\ ${ }^{I}$ Department of Fisheries and Watershed Management, Kwame Nkrumah University of Science and Technology, Kumasi, Ghana; \\ ${ }^{2}$ Department of Animal Science and Production, Sokoine University of Agriculture, Morogoro, Tanzania; ${ }^{3}$ Institute of Aquaculture, \\ University of Stirling, FK9 4LA, Stirling, UK.
}

\begin{abstract}
The nutritional suitability and cost effectiveness of cottonseed meal (CSM) as protein source in the diet of Nile tilapia (Oreochromis niloticus $\mathrm{L}$.) with mean initial weight $4.24 \pm 0.20 \mathrm{~g}$, was evaluated over a 56-day growth period. Four isonitrogenous $\left(320 \mathrm{~g} \mathrm{~kg}^{-1}\right)$, isolipidic $\left(100 \mathrm{~g} \mathrm{~kg}^{-1}\right)$ and isoenergetic $\left(18 \mathrm{KJ} \mathrm{g}^{-1}\right)$ test diets were formulated in which CSM protein replaced fish meal (FM) protein at levels of $0 \%$ (control), 25\%, 50\% and 75\%. The control diet had FM as the sole protein source. The growth experiment was conducted in plastic tanks in a recirculation system each dietary treatment was in triplicate. After 56 days of feeding fish at $6 \%-4 \%$ body weight per day, CSM protein replacements of $25 \%$ and $50 \%$ did not significantly $(\mathrm{P}<0.05)$ affect growth (Specific Growth Rate, Weight Gain) and feed utilization (Feed Intake, Feed Conversion Ratio, Protein Efficiency Ratio, Apparent Net Protein Utilization and Energy Retention). However, the highest replacement level (75\%) significantly reduced these parameters compared to the control diet and this was attributed to low levels of lysine, methionine and threonine and also to high levels of gossypol, trypsin inhibitors saponin and phytic acid in the diet. In terms of cost effectiveness, all the CSM based diets were more profitable than the control. The study indicated that CSM could replace at least 50\% of fish meal protein in the diet of $O$. niloticus without adversely affecting growth and feed utilization and the most cost effective diet was also the diet with 50\% inclusion level of CSM. @JASEM
\end{abstract}

With the increase in intensive aquaculture, demand for more efficient dry diets for fish is rising. Feed is the principal operating cost in the production of fish and the main protein source has traditionally been fish meal (Glencross et al., 2007). Fish meal supports good fish growth because of its protein quality and palatability however, it is often scarce and expensive. According to Rumsey (1993) cost effective practical aquaculture feeds can be produced without the use of fish meal with no apparent loss in fish growth in some species such as tilapia. Despite the fact that most plant ingredients are readily available at a lower cost than fish meal, their use within aquafeeds is usually restricted by relatively low protein content, unbalanced essential amino acid profile, high levels of fibre and starch and the presence of one or more antinutritional factors (NRC, 1993). Oilseeds and their by-products frequently constitute a major source of dietary protein within aquaculture feeds for warm water omnivorous/herbivorous fish species such as those commonly used in African aquaculture, including tilapias (Oreochromis spp.) and catfishes (Clarias spp.) due to their relatively high protein content and low cost.

Cottonseed meal (CSM) which is a by-product of cotton after fibre and oil production is often used as a component in domestic animal feeds due to its relatively high protein content. Some work has been done on the nutritional value of cottonseed meal for tilapia (Jackson et al., 1982; 1984; El-Sayed, 1990; Mbahinzireki et al., 2001; El-Saidy and Gaber, 2003). Literature on the effects of feeding CSM to tilapia is contradictory. While the majority of investigators have recommended inclusion of CSM at levels not exceeding 50\% (Ofojekwu and Ejike, 1984; Mbahinzireki et al., 2001), a few have even indicated that CSM could totally substitute animal protein in tilapia diets (Jackson et al., 1982; ElSayed, 1990). The extent to which CSM may substitute fish meal protein is limited by the level of gossypol and other antinutrients in it (Mbahinzireki et al., 2001).

In recent years intensification of Nile tilapia, Oreochromis niloticus (the main cultured fish) production in Ghana and expansion of aquaculture has generated the need for development of suitable feeds. In contrast to quality commercial poultry feeds that are readily available in Ghana, there is an acute paucity of nutritionally sound, cost effective feeds for finfish, in general, and for Nile tilapia in particular. The use of fish meal at high levels in fish feeds is not feasible in Ghana because of its high price and limited supply, in contrast there is a large number of oilseed and cereal by-products available, a good example being CSM, which is cheap and readily available. Very few locally available plant products have been evaluated in fish feed in Ghana (OduroBoateng, 1986; Oduro-Boateng and Bart-Plange, 1988; Amisah et. al, 2009; Agbo et. al, 2009) and other unpublished studies. This study evaluated the nutritional value of CSM in practical diets for $O$. niloticus using locally available CSM by assessing its effects on growth, feed utilization and cost effectiveness.

\section{MATERIALS AND METHODS}

Experimental system and fish handling: This study was conducted at the tropical aquarium of the Institute of Aquaculture, University of Stirling, UK. Fish were reared in plastic tanks $(30 \mathrm{~L})$ in a recirculation system which was supplied with aerated water at a flow rate of $1 \mathrm{~L} \mathrm{~min}^{-1}$ with temperature maintained at $27 \pm 1^{\circ} \mathrm{C}$. Fish were subjected to a constant photoperiod of 12 hours Light/12 hours Darkness. Water quality parameters measured weekly during the experiment were as follows (mean $\pm \mathrm{SD}$ ): 
Effects of dietary cottonseed meal protein.....

temperature, $26.93 \pm 0.35^{\circ} \mathrm{C} ; \mathrm{pH}, 7.29 \pm 0.18$; ammonia, $0.05 \pm 0.02 \mathrm{mg} \mathrm{L}^{-1}$; nitrite, $0.20 \pm 0.0 \mathrm{mg}$ $\mathrm{L}^{-1}$; nitrate, $20 \pm 0.0 \mathrm{mg} \mathrm{L}^{-1}$ and dissolved oxygen, $7.39 \pm 0.57 \mathrm{mg} \mathrm{L}^{-1}$. Twenty mixed-sex O. niloticus known as the "Red-stirling strain" of mean weight of $4.24 \pm 0.20 \mathrm{~g}$ were stocked randomly into plastic tanks in triplicates per treatment. One week before the start of this experiment fish were transferred to the experimental tanks from nursery tanks for acclimation. For initial and final samples, all fish were individually weighed under anaesthesia with Benzocaine (50 $\mathrm{mg} \mathrm{L}^{-1}$ ).

Diet formulation and preparation: Cottonseed meal (crude protein, $441.4 \mathrm{~g} \mathrm{~kg}^{-1}$ ) used in this study was obtained from commercial sources in Ghana however, fish meal (crude protein, $716.3 \mathrm{~g} \mathrm{~kg}^{-1}$ ) and wheat grain (crude protein, $95.2 \mathrm{~g} \mathrm{~kg}^{-1}$ ) were supplied by Ewos Ltd (Bathgate, UK). Four isonitrogenous (320 $\mathrm{g} \mathrm{kg}^{-1}$ protein), isolipidic (100 $\mathrm{g} \mathrm{kg}^{-1}$ lipid) and isoenergetic $\left(18 \mathrm{KJ} \mathrm{g} \mathrm{g}^{-1}\right)$ diets were formulated for this experiment (Table 1) to satisfy the nutrient requirements of Nile tilapia (NRC, 1993). The control diet was formulated with fish meal as the sole source of protein and this was replaced at different levels with CSM protein at inclusion levels of $25 \%$, $50 \%$ and $75 \%$ (designated as CSM25, CSM50 and CSM75). All ingredients were finely ground and sieved through a $790 \mu \mathrm{m}$ sieve before being weighed and mixed uniformly in a Hobart A200 Mixer (Hobart Co Ltd, England). Water was added (20\%$30 \%$ ) to the mixture with continuous stirring until a dough was formed. A Pellet Mill (CL2 model, California) was used to pellet the diets using a $1 \mathrm{~mm}$ die and then air dried using an electric fan convector heater at $35-40^{\circ} \mathrm{C}$ for 24 hours. The diets were stored at $-20^{\circ} \mathrm{C}$ until fed. Fish were hand-fed twice a day $(10: 00,16: 00)$ at a rate of $6 \%-4 \%$ of their body weight per day (fish were initially fed to satiety before the feeding rates were determined). Feeding rates were adjusted every week and the experiment lasted eight weeks (56 days).

Table 1 Composition of diets ( $\mathrm{g} \mathrm{kg}^{-1}$ as-fed) fed to Nile tilapia with varying inclusion levels of cottonseed meal (CSM) protein.

\begin{tabular}{|c|c|c|c|c|c|}
\hline \multirow[b]{2}{*}{ Ingredients } & Control & CSM25 & CSM50 & CSM75 & \multirow{2}{*}{$\begin{array}{l}\text { *Price of ingredients } \\
\left(\mathrm{Gh} \phi \mathrm{kg}^{-1}\right)\end{array}$} \\
\hline & 1 & 2 & 3 & 4 & \\
\hline Cottonseed meal & - & 170.5 & 341.0 & 511.0 & 0.18 \\
\hline Fish meal $^{1}$ & 420.0 & 315.0 & 210.0 & 105.0 & 1.17 \\
\hline Wheat grain & 203.0 & 204.0 & 204.0 & 208.0 & 0.10 \\
\hline Sunflower oil & 57.0 & 61.5 & 66.0 & 70.5 & 0.50 \\
\hline$\alpha$-cellulose & 30.0 & 15.0 & - & - & 0.05 \\
\hline Corn starch & 205.0 & 149.0 & 94.0 & 20.5 & 0.10 \\
\hline $\mathrm{CMC}^{2}$ & 25.0 & 25.0 & 25.0 & 25.0 & 0.25 \\
\hline Mineral premix ${ }^{3}$ & 40.0 & 40.0 & 40.0 & 40.0 & 1.50 \\
\hline Vitamin premix ${ }^{4}$ & 20.0 & 20.0 & 20.0 & 20.0 & 1.45 \\
\hline Diet cost, $\mathrm{Gh} \varnothing \mathrm{kg}^{-1}$ & 0.56 & 0.47 & 0.37 & 0.27 & - \\
\hline
\end{tabular}

${ }^{1}$ Brown fish meal (aquaculture grade), ${ }^{2}$ Carboxymethyl cellulose (sodium salt, high viscosity), ${ }^{3} \mathrm{Contained} \mathrm{(as} \mathrm{g} \mathrm{kg}{ }^{-1}$ of diet): $\mathrm{MgSO}_{4}, 7 \mathrm{H}_{2} \mathrm{O}, 20.40 ; \mathrm{NaCl}, 8.00 ; \mathrm{KCl}, 6.04 ; \quad \mathrm{Fe} \mathrm{SO}_{4}, 7 \mathrm{H}_{2} \mathrm{O}, 4.00 ; \mathrm{ZnSO}_{4}, 4 \mathrm{H}_{2} \mathrm{O}, 0.88 ; \quad \mathrm{MnSO}_{4}, 4 \mathrm{H}_{2} \mathrm{O}_{2}, 0.41 ; \quad \mathrm{CuSO}_{4}, 5 \mathrm{H}_{2} \mathrm{O}, 0.13 ;$ $\mathrm{CoSO}_{4}, 7 \mathrm{H}_{2} \mathrm{O}, 0.08 ; \mathrm{CaIo}_{3}, 6 \mathrm{H}_{2} \mathrm{O}, 0.05 ; \mathrm{CrCl}_{3}, 6 \mathrm{H}_{2} \mathrm{O}, 0.02$ (according to Jauncey and Ross 1982). ${ }^{4} \mathrm{Contained}$ (as mg kg ${ }^{-1}$ of diet): Thiamine $\left(\mathrm{B}_{1}\right)$, 85.00; Riboflavin $\left(\mathrm{B}_{2}\right)$, 60.00; Pyridoxine $\left(\mathrm{B}_{6}\right)$, 25.00; Pantothenic acid, 105.00; Inositol, 500.00; Biotin, 1.80; Folic acid, 20.00; Ethoxyquin, 4.00; Choline, 1481.00; Nicotinic acid (Niacin), 250.00; Cyanocobalamin (B 12 ), 0.03; Retinol palmitate(A), 20.00; Tocopherol acetate (E), 140.00; Ascorbic acid (C), 750.00; Menadione (K), 30.00; Cholecalciferol ( $\mathrm{D}_{3}$ ), 0.08 (according to Jauncey and Ross 1982). *Only prices of ingredients with variable inclusion levels were used to calculate diet costs in Ghana cedis (USD $1.00=$ Gh $\varnothing$ 0.90 , based on 2007 exchange rates).

Biochemical composition: Ingredients and diets were analysed in triplicates for proximate composition according to standard methods (AOAC, 1990). Energy was determined using an Adiabatic Autobomb Calorimeter (Parr 6100, USA) with benzoic acid as a standard. Amino acid content was analysed using LKB 4151 Alpha-Plus Amino Acid Analyser (LKB Biochrom Ltd, UK). Phosphorus was measured following the method by Stirling (1985) using a spectrophotometer (Cecil Elegant Technology-Aquarius-P). Some antinutritional factors such as phytic acid, trypsin inhibitors, gossypol and saponin were analysed following earlier methods used by Agbo et al. (2009).

Analysis of biological parameters: Performance in growth and feed utilisation were determined in terms of weight gain (WG), specific growth rate (SGR), feed intake (FI), feed conversion ratio (FCR), protein efficiency ratio (PER), apparent net protein utilization (ANPU) and energy retention (ER) as follows: WG $(\%)$ = final body weight - initial body weight/ initial body weight $x 100$. SGR $\left(\%\right.$ day $\left.^{-1}\right)=$ $100 \times[\ln ($ final body weight)- $\ln ($ initial body weight)]/no. of days. FI $(g)=$ Total feed intake per fish/no. of days, FCR = feed intake/live weight gain, PER = live weight gain/crude protein intake, ANPU $(\%)=100 \times($ final fish body protein $(\mathrm{g})-$ initial fish body protein $(\mathrm{g}))$ /crude protein intake $(\mathrm{g})$, ER $(\%)=$ $100 \times$ (final fish body energy - initial fish body energy)/gross energy intake 
Cost effectiveness of diets: Cost effectiveness of diets was assessed using Profit Index (PI) according to ElSayed (1990) as follows; PI = value of fish/cost of feeding. The value of fish and cost of diets were calculated using market prices in Ghana cedis (Ghф) per kilogramme.

Statistical analysis: Each experimental diet was fed to three groups of fish in a completely randomized design. Statistical analyses in this study were conducted using SPSS Statistical Package (Version 15.0, SPSS Inc., Chicago, IL). Data were subject to one-way ANOVA and the Tukey's Multiple
Comparison Test applied to evaluate differences between means at $\mathrm{p}<0.05$. All percentages were arcsine transformed before analysis.

\section{RESULTS AND DISCUSSIONS}

Proximate composition, energy, phosphorous contents and antinutritional factors of the experimental diets are presented in Table 2. The essential amino acid (EAA) contents of all the diets, except for methionine and threonine, were sufficient to satisfy the EAA requirements of the fish (Table 2) except Diet 4, which was deficient in lysine as well.

Table 2 Biochemical composition of diets fed to Nile tilapia in this study

\begin{tabular}{|c|c|c|c|c|c|}
\hline \multirow{2}{*}{\multicolumn{2}{|c|}{ Proximate composition ( $\mathrm{g} \mathrm{kg}^{-1}$ as-fed) }} & Control & CSM25 & CSM50 & CSM75 \\
\hline & & 1 & 2 & 3 & 4 \\
\hline \multicolumn{2}{|c|}{ Dry matter } & 936.1 & 938.9 & 941.2 & 944.0 \\
\hline \multicolumn{2}{|l|}{ Crude protein } & 331.9 & 323.9 & 318.2 & 321.1 \\
\hline \multicolumn{2}{|l|}{ Crude lipid } & 102.2 & 102.7 & 95.6 & 95.1 \\
\hline \multicolumn{2}{|l|}{ Crude fibre } & 33.0 & 45.6 & 58.5 & 73.3 \\
\hline \multicolumn{2}{|l|}{ Ash } & 95.4 & 94.1 & 93.3 & 93.4 \\
\hline \multicolumn{2}{|l|}{ Nitrogen free extract } & 373.6 & 372.6 & 375.6 & 361.1 \\
\hline \multicolumn{2}{|c|}{ Gross energy, $\left(\mathrm{kJ} \mathrm{g}^{-1}\right)$} & 18.66 & 18.32 & 18.17 & 18.49 \\
\hline \multicolumn{6}{|c|}{ Essential amino acid composition (\% of dietary protein) } \\
\hline $\begin{array}{lll} & \\
& 4.20^{1} & 5.01\end{array}$ & $4.20^{1}$ & 5.01 & 5.80 & 6.58 & 7.37 \\
\hline Histidine & 1.70 & 1.99 & 2.13 & 2.27 & 2.40 \\
\hline Isoleucine & 3.10 & 3.96 & 3.74 & 3.52 & 3.30 \\
\hline Leucine & 3.40 & 6.41 & 6.15 & 5.88 & 5.62 \\
\hline Lysine & 5.10 & 6.23 & 5.79 & 5.34 & 4.90 \\
\hline Methionine + Cystine ${ }^{2}$ & 2.70 & 2.72 & 2.46 & 2.21 & 1.95 \\
\hline Phenylalanine + Tyrosine ${ }^{2}$ & 3.80 & 5.26 & 5.56 & 5.85 & 6.14 \\
\hline Threonine & 3.80 & 3.23 & 3.15 & 3.07 & 2.98 \\
\hline Valine & 2.80 & 4.94 & 4.73 & 4.51 & 4.29 \\
\hline \multicolumn{6}{|c|}{ Phosphorous and antinutritional factors $\left(\mathrm{g} \mathrm{kg}^{-1}\right)$} \\
\hline \multicolumn{2}{|c|}{ Phosphorus } & 9.08 & 9.62 & 8.57 & 9.67 \\
\hline \multicolumn{2}{|l|}{ Phytic acid } & 0.5 & 5.9 & 11.3 & 16.7 \\
\hline \multicolumn{2}{|l|}{ Trypsin inhibitors } & 0.0 & 0.2 & 0.4 & 0.6 \\
\hline \multicolumn{2}{|l|}{ Gossypol } & 0.0 & 1.0 & 3.9 & 5.8 \\
\hline \multicolumn{2}{|l|}{ Saponin } & 1.1 & 2.3 & 3.4 & 4.5 \\
\hline
\end{tabular}

${ }^{1}$ EAA requirements for tilapia (NRC, 1993), ${ }^{2}$ The values for methionine and phenylalanine are the requirements in the presence of cystine and tyrosine of the diet respectively.

Growth responses of Nile tilapia fingerlings to the experimental diets are presented in Table 3. From the study it was observed that growth responses were significantly affected by inclusion level of CSM protein. In general, growth rate decreased with increasing level of CSM in the diet. With respect to SGR, Diet 4 was significantly lower compared to the control. This meant that diets with 50\% CSM protein inclusion and below had SGRs which were not significantly different from the control.

Feed intake of the different diets ranged between $23.76 \mathrm{~g}$ and $35.03 \mathrm{~g}$ per fish at the end of the experiment. Feed intake reduced with the increase in inclusion level of CSM protein. Food conversion ratio (FCR) followed the same trend as SGR except that Diet 2 (CSM25) had the lowest FCR (2.05) and Diet 4 (CSM75) the highest (3.91). FCRs of Diets 2 and 3 were not significantly different from that of the control (Table 3). Protein utilization efficiency followed the same trend as FCR with Diet 2 having the highest PER (1.51) and ANPU (22.01) and Diet 4 the lowest PER (0.82) and ANPU (11.62). PER and PPV for Diet 4 were significantly lower than the control and the other diets (2 and 3). Energy utilization followed exactly the same trend as PER and ANPU.

The results showed that growth performance and feed utilization decreased as CSM inclusion level increased from $25 \%$ to $75 \%$ (the decrease was pronounced between $50 \%$ and $75 \%$ ). Growth and feed utilization were not significantly different ( $\mathrm{p}>$ 0.05) between Diet 2 (CSM25), Diet 3 (CSM50) and the control. However, growth of fish fed Diet 4 (CSM75) was significantly $(p<0.05)$ lower than for the control and the other CSM based diets. This study demonstrated that up to $50 \%$ CSM protein could be used to replace fish meal protein in the diet of tilapia without affecting overall growth and feed utilization of fish. Beyond that level, however, growth was depressed drastically. These results are consistent with similar work done by Mbahinzireki et al. (2001) on tilapia and reported depressed growth and even 
Effects of dietary cottonseed meal protein.....

mortality in fish when they were fed up to $100 \%$ CSM of the dietary protein and recommended an inclusion level of up to $50 \%$. Similarly, Fagbenro and Davies (2000) reported growth retardation and poor feed utilization in tilapia when CSM protein replaced $67 \%$ of fish meal protein. Ofojekwu and Ejike (1984) reported that CSM could not be used as a sole protein source for $O$. niloticus because the fish exhibited poor growth, food conversion and specific growth rate when fed diets with CSM as sole protein source. These findings contradicted an earlier report by Jackson et al. (1982) that tilapia grew well on CSMbased protein, even at $100 \%$ level of inclusion.

Table 3 Growth and feed utilization (per fish) of Nile tilapia fed cottonseed meal based diets and their cost effectiveness for 56 days

\begin{tabular}{lllll}
\hline & Control & CSM25 & CSM50 & CSM75 \\
\cline { 2 - 5 } Growth and feed utilization & 1 & 2 & 3 & 4 \\
\hline Initial weight, g & $4.22 \pm 0.13$ & $4.13 \pm 0.19$ & $4.29 \pm 0.19$ & $4.42 \pm 0.06$ \\
Final weight, g & $19.53 \pm 1.97^{\mathrm{a}}$ & $18.79 \pm 0.90^{\mathrm{a}}$ & $17.92 \pm 0.96^{\mathrm{a}}$ & $10.61 \pm 0.81^{\mathrm{b}}$ \\
Weight gain, \% & $363.79 \pm 59.10^{\mathrm{a}}$ & $356.02 \pm 31.14^{\mathrm{a}}$ & $319.06 \pm 39.48^{\mathrm{a}}$ & $140.21 \pm 16.97^{\mathrm{b}}$ \\
SGR, \%.day & $-1.73 \pm 0.23^{\mathrm{a}}$ & $2.70 \pm 0.13^{\mathrm{a}}$ & $2.55 \pm 0.17^{\mathrm{a}}$ & $1.56 \pm 0.13^{\mathrm{b}}$ \\
Survival, \% & $2.33 \pm 5.77$ & $91.67 \pm 10.41$ & $83.33 \pm 7.64$ & $86.67 \pm 7.64$ \\
Feed conversion ratio & $2.31 \pm 0.25^{\mathrm{a}}$ & $2.05 \pm 0.18^{\mathrm{a}}$ & $2.39 \pm 0.34^{\mathrm{a}}$ & $3.91 \pm 0.84^{\mathrm{b}}$ \\
Feed intake, g & $35.03 \pm 2.39^{\mathrm{a}}$ & $30.02 \pm 1.87^{\mathrm{a}}$ & $32.35 \pm 3.72^{\mathrm{a}}$ & $23.76 \pm 2.19^{\mathrm{b}}$ \\
PER & $1.31 \pm 0.13^{\mathrm{a}}$ & $1.51 \pm 0.13^{\mathrm{a}}$ & $1.34 \pm 0.20^{\mathrm{a}}$ & $0.82 \pm 0.18^{\mathrm{b}}$ \\
ANPU, \% & $20.27 \pm 2.07^{\mathrm{a}}$ & $22.01 \pm 1.98^{\mathrm{a}}$ & $17.55 \pm 2.38^{\mathrm{a}}$ & $11.62 \pm 2.95^{\mathrm{b}}$ \\
Energy retention, \% & $14.09 \pm 1.48^{\mathrm{a}}$ & $17.35 \pm 1.44^{\mathrm{a}}$ & $13.48 \pm 2.00^{\mathrm{a}}$ & $6.72 \pm 1.59^{\mathrm{b}}$ \\
Cost effectiveness of diets fed to fish & & & \\
Feeding cost, Gh $\phi \mathrm{kg}^{-1}$ & 0.020 & 0.014 & 0.012 & 0.007 \\
Value of fish, Gh $\mathrm{kg}^{-1}$ & 0.031 & 0.029 & 0.027 & 0.013 \\
Profit index & 1.55 & 2.07 & 2.25 & 1.85 \\
\hline
\end{tabular}

$\mathrm{SGR}=$ Specific growth rate, $\mathrm{PER}=$ Protein efficiency ratio, ANPU = Apparent net protein utilization. Values are means \pm SD $(\mathrm{n}=3)$ and values within the same row with different letters are significantly different $(P<0.05)$.

The prices of ingredients used in this study are presented in Table 1. Price of tilapia $2.00 \mathrm{Gh} \mathrm{kg}^{-1}$ (USD $1.00=\mathrm{Gh} \phi 0.90$ in 2007 ). NB: Only the costs of feed were considered, other costs were considered to be constant.

Diet 4 (CSM75) was less utilized for growth compared to the other diets because feed intake was lowest (Table 3). The low feed intake and feed utilization could be attributed to the high fibre content (due to higher inclusion level of CSM) as well as high saponin levels of the diets (Table 2) which may have accounted for its poor palatability and digestibility. According to Guillaume and Metailler (1999) the astringent taste of saponin could reduce feed intake. Poor growth performance and feed utilization in this study may be attributed to low levels of lysine, methionine and threonine and also to high levels of antinutritional factors (Table 2) namely; gossypol, trypsin inhibitors with tolerant levels reported to be $1.6 \mathrm{~g} \mathrm{~kg}^{-1}$ and phytic acid below $5 \mathrm{~g} \mathrm{~kg}^{-1}$ for tilapia (Francis et al., 2001).

Results of cost analysis of diets used in this experiment are presented in Table 3. The economics of feed production indicated that the cost of the diets (Table 1) reduced with increase in inclusion levels of CSM. This was due to the low price of CSM (0.18 $\mathrm{Gh} \varnothing \mathrm{kg}^{-1}$ ) which was more than six times lower than that of FM (1.17 $\left.\mathrm{Gh} \mathrm{kg}^{-1}\right)$. After 56 days of feed trial generally, Profit Indices of the CSM based diets were higher than that of the control. Cost effectiveness analysis of the present study generally indicated that the CSM diets are more profitable than the control diet and on the average $50 \%$ replacement was more cost effective than at $75 \%$. These results are similar to reports by El-Sayed (1990) on economic evaluation of cottonseed meal, and El-Saidy and Gaber (2003) on a mixture of different plant protein sources for Nile tilapia. Another study by OduroBoateng and Bart-Plange (1988) on brewery wastes for Tilapia busumana also indicated that these sources were more cost effective than FM, even at the total replacement levels. The present feed trial showed that CSM meal base diets were more profitable than the fish meal based diet.

Conclusions: The results from this study indicated that CSM could replace at least $50 \%$ of fish meal protein in the diet of $O$. niloticus without adversely affecting growth and feed utilization. Generally, the CSM diets were more cost effective than the fish meal based diet particularly, CSM replacing 50\% fish meal protein. CSM are locally and readily available in Ghana at much lower prices than imported FM. It is, therefore, more economical to partially replace FM protein with CSM protein at 50\% inclusion level in practical diets of $O$. niloticus. Further research is recommended using the same diet formulation under field conditions, especially semi-intensive system of fish production commonly practised in earthen ponds in Ghana to assess growth performance of Nile tilapia under natural conditions.

Acknowledgement: The authors are grateful to the Ghana Education Trust Fund for financial support.

\section{REFERENCES}

Agbo, NW; Madalla, N; Jauncey, K (2009). The biochemical composition of some Ghanaian oilseed by-products and their digestibility by Nile tilapia, Oreochromis niloticus L. J. Ghana Sci. Assoc. 11, 136-148. 
Amisah, S; Oteng, MA (2009). Growth performance of the African catfish, Clarias gariepinus, fed varying inclusion levels of Leucaena leucocephala leaf meal. J. Appl. Sci. Environ. Manage.13, 21-26.

AOAC (Association of Official Analytical Chemists) (1990). Official Methods of Analysis, 15th edn, AOAC, Arlington, Virginia, USA.

El-Saidy, DMSD; Gaber, MMA (2003). Replacement of fish meal with a mixture of different plant protein sources in juvenile Nile tilapia, Oreochromis niloticus (L.) diets. Aquac. Res., 34, 1119-1127.

El-Sayed, A-FM (1990). Long-term evaluation of cotton seed meal as a protein source for Nile tilapia, Oreochromis niloticus (Linn.). Aquaculture, 84, 315-320.

Fagbenro, OA; Davies, SJ (2000). Use of oilseed meals as fish meal replacers in tilapia diets. The $5^{\text {th }}$ International Symposium on Tilapia in Aquaculture (ISTA 5). 3-6 September, 2000. Brazil.

Francis, G; Makkar, HPS; Becker, K (2001). Antinutritional factors present in plant-derived alternate fish feed ingredients and their effects in fish. Aquaculture, 199, 197-227.

Glencross, BD; Booth, M; Allan, GL (2007). A feed is only as good as its ingredients - a review of ingredient evaluation strategies for aquaculture feeds. Aquac. Nutr., 13, 17-34.

Guillaume, J; Metailler, R (1999). Antinutritional factors. In: Guillaume, J; Kaushik, S; Bergot, P; Metailler, R (Eds.) Nutrition and feeding of fish and crustaceans, Praxis Publishing Ltd, Chichester, UK: INRA/IFREMER.
Jackson, AJ; Capper, BS; Matty, AJ (1982). Evaluation of some plant proteins in complete diets for the tilapia Sarotherodon mossambicus. Aquaculture, 27, 97-109.

Jauncey, K; Ross, B (1982). A guide to Tilapia Feeds and Feeding. Stirling (UK): Institute of Aquaculture, University of Stirling. p. 111.

Mbahinzireki, GB; Dabrowski, K; Lee, KJ; El-Saidy, D; Wisner, ER (2001). Growth, feed utilization and body composition of tilapia (Oreochromis $s p$.) fed with cottonseed meal-based diets in a recirculating system. Aquac. Nutr. 7, 189-200.

NRC (1993). Nutrient Requirements of Fish. National Academy Press, Washington DC, USA.

Oduro-Boateng, F (1986). Studies on the feeding of tilapia discolor in floating cages in Lake Bosomtwi (Ghana). In: Anonymous Proceedings African Seminar on Aquaculture, pp. 115-122. Kisumu, Kenya: International Foundation for Science.

Oduro-Boateng, F; Bart-Plange, A (1988). Pito brewery waste as an alternative protein source to fishmeal in feeds for Tilapia busumana. In: Pullin, RSV; Bhukaswan, T; Tonguthai, K; Maclean JL (Eds.) Second lnternational Symposium on Tilapia in Aquaculture, pp. 357-360. Manila, Philippines: ICLARM Conf. Proc. No. 15.

Ofojekwu, PC; Ejike, C (1984). Growth response and feed utilisation in the tropical cichlid Oreochromis niloticus (Linn.) fed on cottonseedbased artificial diets. Aquaculture, 42, 27-36.

Rumsey, GL (1993). Fishmeal and alternate sources of protein in fish feeds. Aquaculture, 18, 14-19.

Stirling, HP (1985). Chemical and biological methods of water analysis for aquaculturists. Institute of Aquaculture, University of Stirling: 119pp. 